Check for updates

New Delhi

Cite this as: $B M J 2021 ; 372: n 854$ http://dx.doi.org/10.1136/bmj.n854 Published: 30 March 2021

\title{
Covid-19: India sees new spike in cases despite vaccine rollout
}

\section{Anoo Bhuyan}

India is experiencing a sharp spike in covid-19 cases after months of numbers dropping. The rise comes as India celebrates festivals like Holi, religious functions like the Kumbh Mela, and with five states currently involved in elections.

The country's pandemic curve had been flattening by January and February this year but has taken a sharp upward turn since March. On 27 March, India's confirmed active cases on the day were 62632 , the highest seen since October 2020.

Globally, India has had the third highest number of confirmed cases and deaths from covid-19 after Brazil and the US. As of 29 March, India had 12 million cases and 162 ooo deaths from the disease. ${ }^{1}$

Last week, the Indian government acknowledged a "surge in covid-19 cases" and asked states to focus on "stringent containment and public health measures" including increasing testing, tracing, and vaccination. A press release from the government ${ }^{2}$ put the onus for the second wave of infections on "the laxity among everyone." The central government has asked state governments to take this surge in infections seriously, so as to not be "frittering away" the gains of last year's work to bring down numbers.

Srinath Reddy, president of the Public Health Foundation of India, said there has been a "perfect storm" of reasons for the spike. "The recent rapid upswing in cases is from a confluence of careless crowd behaviours, slackening of governmental vigil, and mutations of the virus." He said that the decline in deaths between October 2020 and January 2021, "gave rise to a popular belief that the danger has fully passed, reinforced by overly confident assertions by some experts and politicians that we have attained herd immunity."

The western state of Maharashtra contributed the bulk of active cases in India throughout the pandemic and in this current surge. As on 28 March 2021, Maharashtra had 320000 active cases of covid-19, far ahead of the second highest state of Kerala, which has 24578 active cases. According to a recent government assessment, ${ }^{3}$ Maharashtra accounts for $62 \%$ of all active cases in the country.

\section{Indian vaccines}

India's ability to control the spread of covid-19 and its demand for and supply of vaccines will impact global supply. According to government data, ${ }^{4} 74$ countries are currently using vaccines made in India. In total, India has supplied 60 million doses to the world-8.1 million have been grants to counties including Bangladesh, Bhutan, Myanmar, and Nepal. ${ }^{4}$ Some 34 million have been commercial sales, and 18 million have been given to Covax.

India began its covid-19 vaccination programme on 16 January. Initially, it was only for health and frontline workers. On 1 March, this was expanded to everyone older than 60 , and those older than 45 who have specific comorbidities. So far, it has administered over 60 million vaccinations, placing it third globally after China and the US. ${ }^{5}$

\section{New variants}

India began its genomic sequencing project for covid-19 last year but, according to a paper ${ }^{6}$ published by Indian government scientists involved in the sequencing, its pace and volume has been insufficient when compared with India's high number of cases.

A recent press statement ${ }^{7}$ from the government said that even though variants of concern have been found in India, they have not been detected in high enough numbers to either establish a direct relationship or explain the rapid surge in cases.

In total, Indian government laboratories have done the genome sequencing of 10787 samples of SARS-CoV2 to look for variants, and found 771.

\section{Another lockdown?}

The Indian government has not enforced another national lockdown as it did in the early months of the pandemic, but the chief ministers of different states have not ruled it out.

In Maharashtra, the chief minister Udhav Thackeray has said repeatedly that another lockdown could be imposed if case numbers continue rising. The government has instead imposed a night curfew, restricting movement after dark. Earlier this month, the state published guidelines ${ }^{8}$ insisting that private offices continue to work from home and allowing $50 \%$ of their staff to work from office. Theatres and auditoriums have also been told to function at $50 \%$ capacity.

In Delhi, the national capital, the chief minister has said that a lockdown would not be a solution, and that people should "learn to live" with the disease instead. ${ }^{9}$ The Delhi government has announced that there will be random testing for SARS-CoV2 at public places. The civic corporation in Mumbai, the capital city of Maharashtra, has said the same.

Fines ${ }^{10}$ for not wearing a mask have increased in some states. Many states insist on a negative RT-PCR test result for covid-19 in order to be allowed entry into the state via flight or road. Public gatherings like weddings have been given caps on how many guests can be allowed. Festival celebrations have been barred $^{11}$ in public, although the restriction has not so far been strictly enforced. ${ }^{12}$

\footnotetext{
Coronavirus update (live). www.worldometers.info/coronavirus. Ministry of Health and Family Welfare. Surge in covid-19 cases. 27 March 2021. https://pib.gov.in/PressReleasePage.aspx?PRID=1708061.
} 
3 Ministry of Health and Family Welfare. With $80 \%$ of daily new cases, Maharashtra, Punjab, Chhattisgarh, Karnataka, Gujarat, and Madhya Pradesh continue to exhibit a spike. 27 March 2021. PIB Delhi. https://pib.gov.in/PressReleasePage.aspx?PRID=1708008.

4 Ministry of Health and Family Welfare. Export of vaccine to other nations. 23 March 2021. PIB Delhi. https://pib.gov.in/PressReleasePage.aspx?PRID=1706942.

5 Statistics and Research. Coronavirus (covid-19) vaccinations. https://ourworldindata.org/covidvaccinations

6 Srivastava S, Banu S, Singh P, Sowpati DT, Mishra RK. SARS-CoV-2 genomics: An Indian perspective on sequencing viral variants. https://link.springer.com/article/10.1007/s12038-021 00145-7.

7 Ministry of Health and Family Welfare. Genome sequencing by INSACOG shows variants of concern and a novel variant in India. 24 March 2021. https://pib.gov.in/PressReleasePage.aspx?PRID=1707177.

8 Indian Express. Maharashtra issues new covid-19 guidelines: private offices to function at 50\% capacity, govt ones to stagger timings. https://indianexpress.com/article/india/maharashtra-issuesnew-covid-19-guidelines-50-capacity-for-private-offices-theatres-till-march-31-7235903.

9 Lockdown not a solution, learn to live with covid": Delhi health minister. www.ndtv.com/indianews/coronavirus-delhi-lockdown-not-a-solution-learn-to-live-with-covid-delhi-health-ministersatyendar-jain-2400081.

10 Ojha S. Covid-19 new restrictions: what Delhi, Maharashtra, Gujarat are doing www.livemint.com/news/india/covid19-new-restrictions-what-delhi-maharashtra-gujarat-aredoing-to-fight-the-second-wave-11616888630767.html.

11 Dwivedi S. Random covid tests at Delhi Airport, Railway Station, no Holi in public. www.ndtv.com/india-news/no-holi-celebrations-in-public-places-says-delhi-government-amidrise-in-coronavirus-cases-2397485.

12 Indian Express. Watch: covid rules go for a toss as thousands converge at UP's Banke Bihari Temple to celebrate Holi. https://indianexpress.com/article/india/watch-covid-rules-go-for-a-tossas-thousands-converge-at-ups-banke-bihari-temple-to-celebrate-holi-7250013/

This article is made freely available for use in accordance with BMJ's website terms and conditions for the duration of the covid-19 pandemic or until otherwise determined by BMJ. You may use, download and print the article for any lawful, non-commercial purpose (including text and data mining) provided that all copyright notices and trade marks are retained. 